DOI: https://doi.org/10.18371/fp.3(39).2020.215188

УДК $338.001 .36:[334.722: 65.012 .8]$

\title{
НОВІ ОРІЄНТИРИ ДЕРЖАВНОЇ ЕКОНОМІЧНОЇ ПОЛІТИКИ ЩОДО ФОРМУВАННЯ СПРИЯТЛИВОГО БІЗНЕС-СЕРЕДОВИЩА ТА ЗАБЕЗПЕЧЕННЯ БЕЗПЕКИ БІЗНЕСУ
}

\author{
ІВАНЮК Богдан Михайлович \\ acnipaнm \\ кафедра фінансів, банківського бізнесу та оподаткування \\ Начіональний університет \\ «Полтавська політехніка імені Юрія Кондратюка» \\ ORCID ID: http://orcid.org/0000-0003-1463-1519 \\ e-mail:bivaniuk@chamber.ua
}

Анотація. У статті обтрунтовано та визначено напрями вдосконалення державної економічної політики, які сприяють розвитку бізнес-середовища та дозволяють підвищитти рівень економічної безпеки бізнесу України. Окреслено економічні, сочіальні та інституційні чинники впливу на формування безпекоорієнтованості бізнес-середовища Украӥни. Проведено оцінку впливу пандеміі коронавірусної інфекиії COVID-19 на економічний розвиток Украӥни та світу, визначено основні зміни бізнес-середовища. Зроблено висновок, щуо нагальною є необхідність формування нової державної економічної політики України, яка має бути адаптованою до прояву глобальних викликів, характеру змін бізнес-середовища.

Ключові слова: державна економічна політика, бізнес-середовище, економічна безпека бізнесу.

Постановка проблеми. Стратегічний напрям розвитку України значною мірою обумовлений орієнтованою державною економічною політикою, яка визначається в цілях, завданнях, напрямах і пріоритетах. Державна
Аннотация. $B$ cmaтье обосновано и определены направления совершенствования государственной экономической политики, способствующих развитию бизнес-среды и позволяюших повысить уровень экономической безопасности бизнеса Украинь. Определень экономические, сочиальные и институциональные факторы влияния на формирование безопасноориентированной бизнес-средь Украины. Проведена оиенка влияния пандемии коронавирусной инфекиии COVID-19 на экономическое развитие Украинь и мира, определены основные изменения бизнессреды. Сделан вывод про необходимость формирования новой государственной экономической политики Украины, которая должна быть адаптированной к проявлению глобальных вызовов и характерних изменений бизнес-среды.

Ключевые слова: государственная экономическая политика, бизнес-среда, экономическая безопасность бизнеса.

політика розвитку сприятливого бізнес-середовища та зміцнення економічної безпеки бізнесу є складною і важливою проблемою, вирішення якої, у свою чергу, стимулює розвиток малого та середнього бізнесу в Україні, 
створює цивілізовані конкурентні умови стабільної діяльності господарюючих суб'єктів.

Особливої актуальності набуває потреба в детальному дослідженні чинників розвитку сприятливого бізнессередовища та зміцнення економічної безпеки бізнесу, які тривалий час накопичувалися в соціальній, економічній та інституційній сфері й залишаються невирішеними, а в умовах світової кризи супроводжуються поглибленням негативних тенденцій.

Аналіз останніх досліджень і публікацій. Особливості та ефективність підприємницької діяльності значною мірою визначаються умовами зовнішнього середовища, в якому функціонує підприємство. Проблеми визначення складових бізнес-середовища, зовнішніх умов ведення бізнесу, конкурентних переваг висвітлені в працях зарубіжних і українських науковців, зокрема Д. Норта, Й. Шумпетера, М. Портера, 3. Варналія [4], М. Козоріз, C. Покропивного та інших. Ефективність державної економічної політики визначається багатьма факторами, які досліджено вченими І. Біла, Н. Насікан [3], О. Комеліної [5], М. Мельник [8], А. Мокій [7] тощо. Моніторинг різних напрямів державної економічної політики щодо формування сприятливого бізнессередовища здійснюють провідні міжнародні організації $[1 ; 9 ; 10 ; 11]$. Проте недостатньо дослідженими залишаються проблеми формування й реалізації державної економічної політики сприяння розвитку бізнессередовища та безпекоорієнтованості в Україні.

Метою дослідження $\epsilon$ особливості формування нової державної економічної політики щодо формування спри- ятливого бізнес-середовища та безпеки бізнесу в умовах глобальних викликів та загроз.

Виклад основного матеріалу. Безпечне функціонування бізнесу в умовах зростаючої кількості глобальних викликів і загроз потребує моніторингу екзогенних та ендогенних факторів розвитку національної економічної системи, комплексний вплив яких визначає параметри безпекоорієнтованості бізнес-середовища. Особливої актуальності набуває потреба в детальному дослідженні зовнішніх загроз економічній безпеці бізнесу, які тривалий час накопичувалися в економічній та інституційній сфері й залишаються невирішеними, а в умовах світової кризи супроводжуються поглибленням негативних тенденцій, та оцінювання впливу негативних чинників бізнес-середовища на розвиток підприємницької діяльності та економічну безпеку бізнесу.

Сучасна економічна наука дає підстави розглядати бізнес-середовище як складну, багато-вимірну, поліфункціональну систему, яка формується суб'єктами економіки та інститутами, a також чинниками правового, політичного, соціального, економічного характеру, які створюють умови функціонування і розвитку бізнесу, здійснення ділових відносин, використання потенціалу, досягнення цілей суб'єктів господарювання $[2 ; 3$; 4, с.127-128]. При цьому швидка зміна зовнішнього i внутрішнього бізнессередовища під впливом нових глобальних викликів, їх вплив на результативність розвитку бізнесу викликають необхідність формування нових підходів з точки зору забезпечення стійкості економіки країн, формування нових підходів щодо управління їх 
розвитком 3 урахуванням інтересів великого, малого та середнього бізнесу і суспільства.

Недостатньо ефективна економічна політика вітчизняних органів державного управління із забезпечення економічної безпеки суб'єктів підприємництва вже сьогодні призводить до таких негативних соціальноекономічних наслідків: сповільнення темпів створення нових підприємств та зайнятості на них, зниження темпів збільшення обсягів податкових платежів до бюджету, погіршення конкурентного середовища; неналежний рівень конкурентоспроможності критичної маси вітчизняних підприємств базових видів економічної діяльності, що має негативні наслідки, враховуючи значні обсяги доданої вартості та чисельності зайнятих; зниження рівня ділової активності населення та підприємств; формування нераціональної структури економіки, посилення депресивності більшості регіонів країни; зниження рівня економічної безпеки територіально-адміністративних систем та національної економіки загалом.

Економічна безпека бізнесу може розглядатися як вагомий критерій оцінювання ефективності державного регулювання розвитку бізнессередовища, здатності державної економічної політики щодо забезпечення інтересів суб'єктів підприємницької діяльності та їх збалансування $з$ інтересами суспільного розвитку, а також забезпечення сталого розвитку бізнесу та структурної збалансованості розвитку економіки. Отже державна економічна політика має забезпечувати сприятливі умови формування бізнессередовища, визначати базисні умови розвитку бізнесу, забезпечувати моде- рнізацію існуючих засобів, методів, інструментів з урахуванням нових координат економічного розвитку та завдань забезпечення економічної безпеки бізнесу в Україні.

Дієвість державної економічної політики щодо формування сприятливого бізнес-середовища та безпеки бізнеса можуть бути оцінені з урахуванням зарубіжних методичних підходів, проте важливими залишаються показники кількості діючих, новостворюваних підприємств, їх життєздатність протягом тривалого періоду часу, ефективність використання ресурсного потенціалу та практично про усі соціальні характеристики бізнесу), а рівень економічної безпеки підприємництва - низький, що де мотивує населення та бізнес вкладати кошти у підприємницьку діяльність [4].

Забезпечення ефективної державної політики щодо створення умов формування ефективного бізнессередовища потребує урахування сукупності чинників та їх оцінювання їх впливу на безпеку бізнесу. Як правило, у науковій літературі виділяють такі чинники розвитку бізнесу як: економічні, політичні, інституційні, інфраструктурні, соціокультурні, психологічні і інші.

До основних чинників забезпечення сталого розвитку бізнесу та його безпеки функціонування, що водночас відображують відповідну сприятливість бізнес-середовища, відносять такі: обмеженість доступу до кредитних ресурсів, що може бути викликано несприятливою кон'юнктурою на фінансовому ринку країни; обмеженість (відсутність) власних фінансових ресурсів підприємств; труднощі отримання інвестицій, кредитів, їх висока вартість; складна і малоефективна систе- 
ма оподаткування, що безпосередньо знижує інноваційну та інвестиційну активність більшості вітчизняних суб'єктів господарювання. Негативний вплив на безпеку бізнесу здійснює i низький рівень платоспроможності населення, що істотно обмежує ємність ринків більшості споживчих товарів и послуг.

Досить вагомими за ступенем впливу на розвиток бізнесу є корупція і бюрократизація (політико-адміністративні чинники). Корупційний характер суспільних відносин, в тому числі і в сфері господарської діяльності, створює штучні бар'єри для ведення бізнесу, розвитку підприємницького потенціалу, креативної складової економіки, руйнує конкурентні засади ведення бізнесу.

Останнім часом посилюється вплив й соціально-культурних чинників, що впливають і на кількісні, і на якісні характеристики розвитку бізнесу (культура ведення підприємництва, рівень розуміння важливості соціальної відповідальності бізнесу, інноваційна активність підприємств тощо). Невпинно зростає роль соціальних чинників, які визначають у тому числі й рівень стабільності соціально-економічного розвитку країни, наявність певних протиріч між різними соціальними групами, виробничим персоналом і роботодавцями, державними структурами i підприємцями, працівниками різних професій тощо.

Не можна не відмітити необхідність прискорення впровадження сучасних технологій ведення бізнесу, ефективність яких підтверджена практикою провідних країн світу, що спрощує формування конкурентних стратегій для вітчизняних підприємств. Вплив організаційних факторів на бізнессередовище та бізнес $є$ результатом не- раціонального 3 позицій забезпечення інноваційних процесів розподілу і поєднання елементів інноваційної діяльності, управлінських функцій, регламентації роботи структурних одиниць на макро- і мікрорівнях. У першу чергу це пояснюється вкрай повільним застосуванням сучасних технологій менеджменту у практичній діяльності як на макрорівні (органами державного та регіонального управління), так і на мікрорівні серед великих, середніх, малих підприємств. В умовах швидкого розвитку інноваційно-інвестиційних технологій та цифровізації економіки це виступає гальмівним фактором сталого розвитку бізнесу та низької конкурентоспроможності вітчизняних товарів та послуг, що пов'язані, перш за все, із високими технологіями.

Вплив технологічних факторів на розвиток економіки і формування бізнес-середовища проявляється через кризу нових технологічних ідей в умовах потреби в інноваціях; технологічної несумісності розробок; відторгнення нових технологічних рішень [5]. Негативний вплив цих чинників на економіку бізнесу може бути досить тривалим в результаті низької результативності управління інноваційними процесами, нерозуміння суті і характеру механізмів їх забезпечення, причин і можливих наслідків для бізнесу.

Останнім часом посилюється вплив психологічних чинників, що також певною мірою визначають сучасні параметри бізнес-середовища та стійкість бізнесу. Ці чинники проявляються, як правило, у результаті зміни психологічного стану суспільства в цілому (рівень стресостійкості, почуття незадоволеності, невпевненості, страху людини тощо), формування негативного соціально-психологічного клі- 
мату в країні, регіонах, на підприємстBax.

Дослідження причин виникнення i особливостей прояву глобальних викликів, їх вплив на бізнес і бізнессередовище економіки країни дозволяє вчасно ідентифікувати ці виклики, визначати масштаби їх можливих наслідків, виявляти «драйвери» розвитку бізнесу в нових умовах бізнессередовища, управляти цими процесами, здійснювати системні заходи щодо усунення негативного впливу цих викликів, а також попередження ï переростання в загрози i кризові явища [14].

Безсумнівно, що головним викликом сьогодні для економіки всіх без винятку країн світу $\epsilon$ пандемія COVID-19. За оцінками фахівців Центру дослідження ризику в Judge Business School при Кембриджському університеті пандемія може коштувати світовій економіці \$82 трлн за умови реалізації сценарію економічної депресії на п'ять найближчих років [18]. За прогнозами реалізації оптимістичного сценарію такі втрати можуть досягти \$3,3 трлн за аналогічний період [19]. Існуючі сценарії наслідків пандемї COVID-19 є досить різними для бізнесу. Окрім цього, вже за першу половину 2020 року відбулися значні зрушення в структурі економіки країн світу, змінилися масштаби і напрямки експортно-імпортних операцій, істотно трансформувалася структура споживання домогосподарств, відбувається широке впровадження в повсякденне життя цифрових технологій i т.д. Такі оцінки наслідків пандемії COVID-19 вимагають додаткових досліджень механізмів адаптації економіки і бізнесу більшості країн світу до нових умов розвитку [20].
В Україні особливості впливу пандемії COVID-19 на формування бізнессередовища та бізнесу проявилися насамперед таким чином: за офіційними даними падіння валового внутрішнього продукту України за шість місяців 2020 року склало $11,4 \%$ в порівнянні 3 аналогічним періодом 2019 року [20].

Масштаби пандеміi COVID-19 Україна визначаються такими даними: за станом на 19 вересня 2020 року в країні 172712 лабораторно підтверджених випадків COVID-19, 3 них 3516 летальних, 76754 пацієнти одужали; за результатами щодобового реєстрації кількість хворих збільшується по всій країні в цілому приблизно на 3240 - 3500 [19]. Результати математичного моделювання розвитку епідемiї COVID-19 в Україні, які провели вчені Національної академії наук України, підтверджують збереження таких темпів захворюваності та кількості смертей на рівні 50 випадків в день, при цьому темпи одужання все ще набагато менше кількості нових інфекцій [19; 20].

Слід констатувати, що в Україні COVID-19 істотно вплине на економічну ситуацію через зміни в співвідношенні попиту та пропозиції товарів i послуг не тільки на внутрішньому ринці, а й на зовнішніх, що, відповідно, призведе до зміни конкурентоспроможності вітчизняного бізнесу. Наприклад, на формування попиту найбільше вплине зміна (зменшення) рівня витрат і інвестицій як з боку компаній, так i 3 боку домогосподарств. При цьому державні витрати істотно збільшуються, але не зможуть повністю компенсувати втрати цих двох категорій. 3 точки зору пропозиції швидше за все будуть спостерігатися зміни в логістичних процесах, наприклад, по- 
страждають ланцюга поставок, особливо ті, які залежать від глобальної торгівлі або складаються з багатьох ланок. Багато міжнародних та національних компаній можуть призупинити або зовсім припинити роботу (сервісний, готельний бізнес, послуги і т. п.). Можливим, на думку експертів, може бути і посилення впливу зарубіжних країн і їх втручання в економіку України через фонди окремих держав Європейського Союзу та відповідні гарантійні схеми, вплив на монетарну політику (стабілізація обмінного курсу, програми випуску облігацій, інші фінансові інструменти) 3 метою попередити економічні ризики, пов'язані 3 COVID-19.

Безсумнівно, будуть вноситися зміни в законодавчій сфері, пов'язані 3 законодавством про банкрутство, попередженням ймовірного виникнення i, відповідно, протидії дефолту, захисту соціальної сфери та соціальних гарантій населенню, які працюють і безробітним і т.п. Наприклад, в Україні вже переглянуті умови отримання i розмір допомоги по безробіттю, при цьому реєстрація безробітних може бути оформлена дистанційно через онлайн-портал державних послуг; підвищено мінімальний розмір допомоги по безробіттю на період карантину та протягом 30 днів після його завершення; зареєстрованим в службі зайнятості безробітним допомога призначається 3 першого дня отримання статусу безробітного. Крім цього, така допомога призначається для тих, хто був звільнений за власним бажанням починаючи 312 березня 2020 року (дата офіційного запровадження національного карантину). Державою було передбачено надання допомоги власникам малого і середнього бізнесу по частковому безробіттю, що дозволяє зберегти робочі місця і зменшити безробіття.

Безумовно, подальше поширення коронавірусної інфекції COVID-19 в Україні призведе і до змін в Державному Бюджеті на 2021 р. Зокрема, визначено нові ключові пріоритети держаної економічної політики країни, що ураховано під час підготовки Держаного бюджету України на 2021 рік. Головними пріоритетами фінансування 3 державного бюджету визначено: 1) безпеку i оборону України $(5,93 \%$ ВВП); 2) охорону здоров'я (до 4,2\% ВВП); 3) економіку - державні гарантії відшкодування відсотків по кредитах, підтримка малого і середнього бізнесу, аграрної сфери; 4) соціальну сфера (освіта, виплата субсидій населенню за платежі за комунальні послуги) [13].

Таким чином, вплив пандемії COVID-19 проявилося у всіх сферах суспільного розвитку, призвело до значних змін як на макро-, так і мікрорівнях, супроводжувалося формуванням нових пріоритетів державної та соціальної політики. Безумовним результатом глобального прояви пандемії коронавірусної інфекції COVID-19 $\epsilon$ етап нових економічних досліджень щодо розробки механізмів стабілізації економіки і забезпечення іiі стійкості через введення додаткових інструментів впливу на розвиток бізнесу і підвищення привабливості бізнессередовища $з$ урахуванням нового формату ринка, зміни попиту і пропозиції, трансформації структури економіки.

Висновки. Таким чином, проведена систематизація чинників формування сприятливого бізнес-середовища та безпеки бізнеса, їх змістовні характе- 
ристики є важливими орієнтирами формування ефективної державної економічної політики в умовах посилення впливу глобальних викликів та дають змогу створити певне підгрунтя для визначення напрямів ії вдосконалення. 3'ясовано, що вимагають переоцінювання роль і вплив традиційних факторів на розвиток бізнесу і формування бізнес-середовища (економічні, політичні, інституційні, інфраструктурні, соціокультурні та інші); впровадження нових, більш дієвих економічних механізмів управління економікою як на рівні підприємств, так і країни в цілому, спрямованих на усунення бар'єрів, перешкод, ризиків, загроз і тощо, які впливають на реалізацію потенціалу розвитку бізнесу в нових умовах. Подальший аналіз проблеми впливу глобальних викликів на розвиток бізнесу і бізнес-середовища країни дозволить розробити дієві механізми подолання ризиків, враховуючи існуючі особливості економічної, політичної і соціокультурної ситуації в Україні.

Отже, нова державна економічна політики України має бути адаптованою до прояву глобальних викликів, характеру змін бізнес-середовища, що дає змогу вчасного корегування довгота середньострокових пріоритетів соціально-економічного розвитку країни і забезпечення сталого розвитку бізнеcy.

\section{Список використаної літератури}

1. Government finance statistics. Summary tables - 2010-2018. Luxembourg: Office for Official Publications of the European Communities. 2018. 31 p.

2. Щербина І.Ф., Рудик А.Ю., Зубенко В.В. та ін. Бюджетний моніторинг: аналіз виконання бюджету за 2019 рік. ІБСЕД, Проект „Зміцнення місцевої фінансової ініціативи".USAID. K.: 2020. 96 с.

3. Біла І.С., Насікан Н.І. Бізнес-середовище в Україні. Глобальні та начіональні економічні проблеми, 2017. Вип. 17. С. 127-131.

4. Варналій 3. С., Васильців Т. Г., Білик Р. Р. Забезпечення конкурентоспроможності та економічної безпеки малого і середнього підприємництва України. Вісник Академї пращі і сочіальних відносин Федераџії профспілок Украӥни, 2015. № 3-4. С. 44-50.

5. Комеліна О.В. Стратегія трансформації інноваційно-інвестиційного простору України: теорія, методологія і практика: монографія. К.: ТОВ «ДКС центр, 2010.

6. Котлер Ф., Касліоне Дж.А. Хаотика: управління та маркетинг в епоху турбулентності (Хаотика: управління та маркетинг в епоху турбулентності). К: Ciмджест, ПЛАСКЕ, 2009. 208 с.

7. Конкурентні стратегії безпеки розвитку України у глобальному середовищі/за. ред.: А. І. Мокій. Львів, 2019. 872 с. 
8. Мельник М. I. Формування бізнес-середовища України в умовах інституційних трансформацій: монографія. Львів: ІРД НАН України, 2012. 568 с.

9. The Open Budget Survey 2019: International Budget Partnership. URL: http://internationalbudget.org/wpcontent/ uploads/OBI2019-Report-English.pdf (дата звернення 12.08. 2020).

10. The world factbook URL: https://www.cia.gov/library/publications/theworldfactbook/rankorder/2186rank.html (дата звернення 12.08. 2020).

11. United Kingdom HM Treasury. URL: http://www.hm-treasury.gov.uk/ (дата звернення 12.08. 2020).

12. Про Стратегію розвитку системи управління державними фінансами: Розпорядження Кабінету Міністрів України від 01.08.2013 р. № 774-p URL: http://zakon2.rada.gov.ua. (дата звернення 12.08. 2020).

13. Міністерство фінансів України. // Офіційний веб-портал. URL: http://www.minfin.gov.ua/ (дата звернення 12.08. 2020).

14. Onyshchenko S., Maslii O., Ivanyuk B. The impact of the external environment on the economic security of Ukrainian business. Economics and Region. 2020. №1 (76). P. 22-29.

15. Holovashchenko V.P., Sydorova A.V. Modern business environment of Ukraine. Bulletin of the student scientific society of DonNU named after Vasyl Stus. URL: http://jvestnik-sss.donnu.edu.ua/article/view/-5631. (дата звернення 12.08. 2020).

16. State Statistics Service of Ukraine Statistic information. URL: http://www.ukrstat.gov.ua/. 2020. (дата звернення 12.08. 2020).

17. Управління та адміністрування в національній економіці: інформаційноаналітичний аспект/за ред. Комеліної О.В. ФОП Пусан А.Ф., 2016. 280 с.

18. Світова економіка може втратити $\$ 82$ трлн за 5 років через пандемію коронавіруса. URL: https://interfax.com.ua/news/economic-/663458.html (дата звернення 12.08. 2020).

19. НАН України прогнозують збільшення добового значення інфікованих коронавірусів. URL: https://interfax.com.ua/news/general-/687485.html (дата звернення 12.08. 2020).

20. Відповіді влади на ключові питання про втрату роботи під час карантину. URL: ligazakon.net/news/195182_otvety-vlasti-na-klychovi-vremya-karantina. (дата звернення 12.08. 2020). 